\title{
THE ANATOMY DEPARTMENT AT UNIVERSITY COLLEGE, DUNDEE, 1888-1954
}

\author{
by
}

\section{R. R. STURROCK*}

IN JUNE 1970 the part of the old Medical School building which housed the Department of Anatomy was badly damaged by fire. In the clearing-up operations which followed, a number of old letters and other documents came to light. Amongst these were all the stubs from the certificates which are sent to Her Majesty's Inspector of Anatomy giving the date of death, cause of death, and age of each cadaver accepted by the department for dissection, and the place from which each cadaver was obtained. As well as enabling causes of death in dissecting-room cadavers to be compared with causes of death in the population as a whole, these documents also showed a major change in attitude of the public towards bequeathing bodies for medical research which only occurred in Dundee from 1952. Until then not a single body had been bequeathed to the Anatomy Department, and the correspondence of the 1920s, '30s and '40s is full of constant references to the difficulty of obtaining cadavers. This change in attitude has probably been due mainly to education; largely by the media, and, as one would have expected, has been a gradual affair. After the first bequest more and more people began to bequeath their bodies, not due to any publicity by the department but spontaneously. In the natural course of events many of these people are still alive, and although there was a sudden increase of offers to leave bodies to the department it has only been over the last few years that the number of bodies actually arriving in the department has increased, and the department has become almost self-sufficient. In this Dundee lags behind all other medical schools in the United Kingdom, because for some time now most other medical schools have had a surfeit of cadavers.

As the change in methods of obtaining cadavers coincided with the change from University College, Dundee, to Queen's College, it seemed appropriate to examine briefly the history of the Department of Anatomy at University College, Dundee. Of all the Scottish anatomy departments it was unique, being the only one with a complete record of the cadavers used from the founding of the department in 1888 until the governing bodies of University College were dissolved by the University of St. Andrews Act of 1953, and University College became completely absorbed into St. Andrews University as Queen's College, Dundee. The reason for the lack of completeness of records at Aberdeen, Edinburgh, and Glasgow Universities is that they are much older foundations, and many of the cadavers were obtained by illegal means. The City of Dundee did not escape the depredations of grave-robbers, one

*R. R. Sturrock, M.B., Ch.B., Department of Anatomy, The University, Dundee, Scotland. 


\section{Short Articles}

of the main villains being Geordie Mill, ${ }^{1}$ the grave-digger at the local cemetery, the Howff. These bodies were removed to Edinburgh for dissection because although a Chair of Medicine and Anatomy had been founded at St. Andrews University by the Duke of Chandos in 1721 its main function seems to have been to award doctorates of medicine ${ }^{2}$ rather than to teach anatomy.

University College, Dundee, was founded in 1882 due to the generosity of the Baxter family. ${ }^{3}$ It was one of the numerous colleges founded in the latter half of the nineteenth century in industrial centres, and its original aims were to prepare students for the external examinations of London University and to organize evening classes for the benefit of the citizens of Dundee. The opening of University College, on 5 October 1883, was celebrated in verse by the well-known local poet William McGonagall.4 At first there were only five chairs: a chair of classics and history; a chair of natural philosophy and mathematics; a chair of chemistry; a chair of engineering and drawing; and a chair of English. In 1884 a chair of biology was founded, followed in 1888 by a chair of botany and a chair of anatomy. Andrew Paterson was appointed to the chair of anatomy which had been endowed by Cox, a local jute magnate. Paterson had arrived in Dundee in 1887 to set up the Anatomy Department and was appointed to the chair at the age of twenty-six. He held the chair until 1894 when he was succeeded by John Yule MacKay, who was to remain Professor of Anatomy until 1925, when he was succeeded in turn by David Rutherford Dow who held the chair until 1958, the last five years in Queen's College. MacKay was also Principal of University College from 1897 until his death in 1930.

University College remained a separate college until 1891 when it became affiliated to St. Andrews University. This affiliation which allowed Dundee a substantial amount of independence while at the same time giving Dundee considerable power in the control of St. Andrews University satisfied no one. The Marquis of Bute, ${ }^{5}$ who became Rector of St. Andrews University, thoroughly detested this arrangement, and succeeded in having the scheme of union annulled in the House of Lords in 1895. This decision, however, was reversed in 1896, and the union came to effect in 1897. The College Council still maintained substantial power and this led to numerous disputes which lasted for over fifty years, until, following the University of St. Andrews Act of 1953, University College was absorbed into St. Andrews University. Queen's College, Dundee, the result of this absorption, lasted until 1967 when it

\footnotetext{
1 G. MacGregor, The history of Burke and Hare, Glasgow, Thomas D. Morrison, 1884, pp. 43-45.

2 R. G. Cant, The University of St. Andrews, Edinburgh, Scottish Academic Press, 1970, pp. 88-89. Cant notes that amongst the honorary M.D.s were Edward Jenner and Jean Paul Marat.

A. D. Walsh, 'Notes on the first visit of the British Association to Dundee and the early history of University College, Dundee', in S. J. Jones (ed.), Dundee and district, Dundee, David Winter, 1968, pp. 374-376.

'W. McGonagall, Last poetic gems, edited by J. L. Smith, Dundee, David Winter, 1968, pp. 86-88.

- The Marquis of Bute founded a Chair of Anatomy at St. Andrews in 1900 after the old Chair of Anatomy and Medicine had been converted into a Chair of Physiology. The St. Andrews PreClinical School Buildings and Student Medical Society were named after him. When Dundee University was founded in 1967, St. Andrews University came to an agreement with Manchester University whereby pre-clinical students at St. Andrews complete their clinical studies at Manchester University. See A. E. Ritchie, 'The St. Andrews Manchester Teaching Amalgamation', St. Andrews Univ. Alumnus Chronicle, 1968, 59: 16-21.
} 


\section{Short Articles}

attained its independent status as the University of Dundee. ${ }^{6}$

In 1898 the Conjoint Medical School of St. Andrews University was established with pre-clinical departments at University College, Dundee, and St. Salvator's College, St. Andrews, and with clinical departments in Dundee associated with Dundee Royal Infirmary.?

In 1904 the Anatomy Department moved into the top floor of the new Conjoint Medical School Building in Dundee where it remained throughout the existence of University College. ${ }^{8}$

In the period 1888 to 1954 University College, Dundee, received 610 cadavers, ${ }^{9}$ only one of which was bequeathed. Three were obtained from the Anatomy Department in St. Andrews, and two from London (one from Guy's, and one from King's) with the help of Her Majesty's Inspector of Anatomy. The remainder were claimed, as permitted by the Anatomy Acts of 1834 and 1871, from local poorhouses, hospitals, etc. A special meeting of the Poorhouse Committee of Dundee Combination Parochial Board held on 7 May 1887 resolved to supply cadavers to the Anatomy Department, and they remained the major source of supply until 1925 when the poorhouses changed their names, if not their function. The successors of the poorhouses continued to supply the majority of cadavers until 1954, but from the early 1940 s the local mental hospitals began to supply a larger proportion of the cadavers. Occasionally bodies were removed from lodging houses, and on one occasion from the Auld Hoose Bar, Perth. Had it not been for the poorhouses and their successors, however, it would have been impossible for the Anatomy Department to have continued teaching.

The certified causes of death of the cadavers were compared with those obtained from the Registrar General (Scotland) Reports, 1888-1954. ${ }^{10}$ Ten-year periods were used because of the relatively small number of cadavers used in any one year. The major causes of death were listed as in the reports, but occasionally changes occurred in the listed causes. When this happened the closest alternative was adopted. This comparison (Table 1) showed no statistically significant correlation between the causes of death in the population at large and those of the dissecting-room cadavers, except in the case of tuberculosis where the correlation was highly significant ( $p<0.001$ ). The cadavers, however, form a highly biased sample, usually being those of elderly people from the poorest part of the population. The incidence of deaths

- For a fuller description of the disputes between St. Andrews and Dundee see Cant, op. cit., note 2 above, pp. $123-140$.

'Ibid., pp. 129-134.

- The Anatomy Department of Queen's College and later Dundee University remained in the Medical School until August 1970 when the Department moved into the new Medical Sciences Institute which it shares with Biochemistry. At the end of June 1970 part of the Department in the Medical School was severely damaged by fire, but the building was repaired and is now occupied by the Physiology Department.

- Of the 610 cadavers one was claimed by a friend before dissection, two were transferred to Aberdeen, twenty-three were transferred to St. Andrews, and twenty-eight were transferred to the Department of Surgery, all for dissection. 556 cadavers were dissected in the Anatomy Department, University College, Dundee.

10 The Registrar General (Scotland) Reports, 34-100, Edinburgh, H.M.S.O., 1888-1954. The form adopted by these reports varies. From 1888-1930 it was possible to select figures for Dundee alone. From 1931-49 the figures for large Burghs were used and from 1950-54 the figures for Cities were used. 


\section{Short Articles}

recorded as due to senility was almost five times greater than the incidence in the population as a whole, as one might have predicted. Certain general trends were evident, such as the increase in incidence of heart disease and malignancy as major causes of death. As very few infant cadavers were obtained the major decrease in infant mortality which occurred over the period in question was not apparent. It is probably worth noting that the influenza pandemic, of 1918 was not reflected in the number of influenza deaths recorded for cadavers in that year, possibly because of the small numbers involved or possibly because the institutions were proportionately less severely affected than the population as a whole. Only ten suicides were recorded between 1888 and 1954. These consisted of five drownings, three carbon monoxide poisonings, one hanging and one carbolic acid poisoning. No drug overdoses were recorded as by 1954 they had not attained their present popularity. The first cadaver who died as a result of a road accident was received in 1942. Sadly one has to wait until 1952, after the advent of the Welfare State, to find for the first time scurvy and starvation being recorded as causes of death (one case of each).

TABLE 1

Percentages of principal causes of death of cadavers in the Anatomy Department at University College, Dundee. The figures in brackets are the percentages for the general population over the same periods, extracted from the Registrar General (Scotland) Reports (see note 8).

\begin{tabular}{|c|c|c|c|c|c|c|c|}
\hline Years & $\begin{array}{c}\text { Tubercu- } \\
\text { losis }\end{array}$ & Cancer & $\begin{array}{l}\text { Cerebro } \\
\text { vascular } \\
\text { accidents }\end{array}$ & $\begin{array}{c}\text { Heart } \\
\text { Disease }\end{array}$ & Bronchitis & Pneumonia & Senility \\
\hline 1888-97 & $16.3(10.7)$ & $10.9 \quad(3.7)$ & $16.3(3.5)$ & $12.6(8.4)$ & $10.0(12.0)$ & $8.8 \quad(8.7)$ & 11.3 \\
\hline $1898-1907$ & $16.2(11.9)$ & $6.8 \quad(5.5)$ & $10.8(5.0)$ & $14.9(10.2)$ & $16.2(9.1)$ & $8.1 \quad(9.5)$ & $13.5(3.2)$ \\
\hline $1908-17$ & $17.4(12.9)$ & $2.9 \quad(7.0)$ & $8.7 \quad(5.6)$ & $17.4(10.4)$ & $11.6(7.7)$ & $11.5(8.6)$ & $5.8 \quad(2.6)$ \\
\hline $1918-27$ & $11.5(8.5)$ & $6.7 \quad(9.4)$ & $3.8 \quad(7.8)$ & $21.2(11.0)$ & $9.6 \quad(6.9)$ & $4.3(11.7)$ & $21.2-$ \\
\hline $1928-37$ & $2.4(6.8)$ & 5.9 (11.5) & $9.5 \quad(9.3)$ & $27.2(15.9)$ & $3.5 \quad(5.9)$ & $\begin{array}{ll}6.0 & (9.9)\end{array}$ & 19.0 \\
\hline $1938-47$ & $2.6 \quad(7.2)$ & $11.8(13.2)$ & $11.8(10.6)$ & $38.2(23.3)$ & $1.3(4.8)$ & $9.2 \quad(5.4)$ & $10.5(2.4)$ \\
\hline $1947-54$ & $-(4.7)$ & $14.5(17.1)$ & $10.1(13.4)$ & $23.2(29.0)$ & $1.4(4.2)$ & $5.8 \quad(3.9)$ & $17.4(1.2)$ \\
\hline
\end{tabular}

The mean age at death of the cadavers increased from 58.9 years in the 1888-97 period to 71.6 years in the 1948-54 period, the major increase in mean age at death occurring between 1888-97 and 1928-37. This was true for both sexes. In all but one period the mean age of death of females was greater than for males (Table 2). This was probably due to the greater longevity of females, this in turn leading to more women outliving their relatives and having no one left to attend to their funerals.

The first cadaver brought into the Department on 19 February 1888 was that of John Garvie. The cause of death was not recorded but he was sixty-seven years of age and had died at home. The youngest cadaver, excluding stillborn children, was 


\section{Short Articles}

that of Rosina Farmer, aged sixteen, who died of phthisis in 1916. The oldest was Mary Doyle or Flynn, who died of chronic bronchitis in the East Poorhouse in April 1905 at the age of ninety-five. It is worth noting that she would have been five years old at the time of Waterloo, and eighteen in 1928 at the time of the trial of Burke.

TABLE 2

Mean age of death of cadavers in years (excluding stillborn) \pm standard deviation.

\begin{tabular}{l|c|c|c}
\hline Years & Overall & Male & Female \\
\hline $1888-97$ & $58.9 \pm 15.2$ & $56.6 \pm 16.0$ & $61.9 \pm 13.6$ \\
$1898-1907$ & $64.5 \pm 13.7$ & $61.6 \pm 14.3$ & $69.6 \pm 11.1$ \\
$1908-17$ & $61.9 \pm 15.2$ & $60.4 \pm 15.5$ & $62.8 \pm 14.7$ \\
$1918-27$ & $66.1 \pm 11.7$ & $66.2 \pm 9.4$ & $65.8 \pm 14.7$ \\
$1928-37$ & $69.9 \pm 9.0$ & $69.2 \pm 7.8$ & $71.0 \pm 10.5$ \\
$1938-47$ & $69.2 \pm 10.5$ & $68.1 \pm 10.7$ & $71.3 \pm 10.4$ \\
$1948-54$ & $71.6 \pm 10.9$ & $69.7 \pm 11.2$ & $75.6 \pm 10.1$ \\
\hline
\end{tabular}

The first, and only bequest of a body to University College, Dundee, took place in December 1952, and was that of Dr. Kate Knowles. Unfortunately few details are available of her life, but those which are indicate she must have been a remarkable woman. She was born in 1866, and some time in the 1880 s she received the certificate of L.L.A. from St. Andrews University. This was an extra-mural qualification for ladies, of equivalent standard to the Scottish M.A. Degree. The letters stood for Ladies Literate in Arts. ${ }^{11}$ Later she studied at the London School of Medicine for Women and was graduated M.B., B.S., in 1904 at the age of thirty-eight. Despite suffering from "marked scoliosis"12 she travelled to India as a medical officer with the Christian Missionary Society at Srinigar where she published a paper on osteomalacia, in the British Medical Journal of $1914 .{ }^{13}$ From India she moved to Australia during the First World War, and worked as a physician in the Rachel Forster Hospital in Sydney. After the War she returned to Scotland and retired to Crieff Hydro Hotel. In June 1952 she wrote to Professor Adam Patrick, the Professor of Medicine at University College, Dundee, stating her desire to leave her body to medical science. She then carried on a lively, and at times heated, correspondence with Professor D. R. Dow on the subject of her bequest, as she wished her skull and skeleton to be retained and wished no part to be buried. This of course would have meant contravening the

${ }^{11}$ R. N. Smart, 'Literate Ladies-a fifty year experiment', St. Andrews Univ. Alumnus Chronicle, 1968, 59: 21-31.

12 This information was included in her letter to Professor Patrick bequeathing her body to the Medical School.

${ }^{18}$ K. Knowles, 'Osteomalacia', Br. med. J., Suppl. 1914, pp. $62-63$. 


\section{Short Articles}

Anatomy Act of 1871 . Her last letter written a fortnight before her death was brief and finally accepted the situation regarding the Anatomy Acts.

Owing to her correspondence with Professor Dow and her professional status it has been possible to piece together a brief biography of Dr. Knowles. Unfortunately this has not been possible for any of the others, and yet their place in the teaching of generations of medical students was equally important. While their bodies arrived in the medical school because of the circumstances of their death, rather than their expressed wishes during their lives, one would hope that their mute, but vital contribution to medical education would not be forgotten.

At the beginning the law-abiding nature of University College, Dundee, was noted, but one possible lapse from grace appears to have occurred in 1889 when the last execution to be carried out in Dundee took place. The cervical vertebrae of the victim are displayed in the Department Museum despite the fact that after the Anatomy Act of 1832 the bodies of executed criminals were no longer turned over to anatomists. How the specimen arrived in the museum is not known, but it clearly shows bilateral vertical fractures between the laminae and the body of the axis which, according to Simpson, ${ }^{14}$ was the commonest cause of death in judicial hanging, and not as is widely believed, tipping back of the odontoid process with compression of the spinal cord. William Bury, aged thirty, was hanged on 24 April 1889 for the murder of his wife. He had arrived by boat in Dundee in January 1889 from London. Before moving to Dundee he had been living in the East End of London where Jack the Ripper was active. Bury, who had mutilated his wife's body after he murdered her, claimed to be the Ripper, and on the way to the scaffold was questioned by James Berry, the hangman, about his connexion with the Whitechapel crimes. According to a local newspaper ${ }^{15}$ "Berry was convinced that the man was indeed the Ripper, as were two Scotland Yard Officers who attended the execution. Certainly there were no more Whitechapel murders of the Ripper style after April 1889". The possibility that Bury was the Ripper seems extremely remote, and he does not figure in any of the popular criminologists' lists. His cervical vertebrae, however, are among the few specimens extant of the results of judicial hanging, and are the closest Dundee comes to having a notorious relic, such as the skeleton of William Burke which now graces the Anatomy Department of Edinburgh University.

\section{SUMMARY}

University College, Dundee, was founded in 1882 and the Chair of Anatomy was endowed in 1888. In 1954 University College became Queen's College, Dundee. During its fifty-five years the Anatomy Department obtained over 600 cadavers, only one by bequest. The causes of death were compared with those of the population at large and only in the case of tuberculosis was there any significant correlation. This was almost certainly due to the fact that almost all the bodies were claimed from the local poorhouses and were those of the oldest and poorest inhabitants.

14 K. Simpson, Forensic medicine, 5th ed., London, Edward Arnold, 1964, p. 100.

15 The details of Bury have been taken from a photograph of an article in the Dundee Evening Telegraph, which accompanies the specimen in the Anatomy Department Museum at Dundee. The article was written when his burial place was uncovered during building operations in the precincts of the Sheriff Court, and unfortunately is undated. 